\title{
Activated Carbon Obtained from Coffee and Orange Wastes
}

\author{
Dorian M. Godínez-Adame ${ }^{1}$, Job A. Díaz-Hernández ${ }^{1}$, Luis E. Álvarez-Jacinto ${ }^{1}$, Ludwig I.C. Ortiz-García ${ }^{1}$, \\ Emily G. Cahum-Chan ${ }^{1}$, Sheila M. Canul-Petul ${ }^{1}$, Claudia B. Santiago-Martínez ${ }^{1}$, Lourdes J. Solís-Uc ${ }^{1} \&$ Jessica \\ Borbolla-Vázquez ${ }^{1}$ \\ ${ }^{1}$ Universidad Politécnica de Quintana Roo, México \\ Correspondence: Jessica Borbolla-Vázquez, Research Professor, Universidad Politécnica de Quintana Roo, \\ Cancún, Quintana Roo, CP: 77500, México. Tel: 52-55-3716-3638. E-mail: jessica.borbolla@upqroo.edu.mx
}

Received: June 13, 2019 Accepted: July 8, $2019 \quad$ Online Published: July 30, 2019

doi:10.5539/jsd.v12n4p140 URL: https://doi.org/10.5539/jsd.v12n4p140

\begin{abstract}
Organic coffee and orange wastes have increased considerably in the last decade. In order to utilize this "garbage", the present study focuses on the obtaining of activated carbon from them. The pyrolysis of the samples, followed by chemical activation and subsequent neutralization, allowed the establishment of two protocols " $\mathrm{A}$ " and "B", with slight variations depending on the residue. The results indicate that the efficiency of the activated carbon from coffee grounds using protocol "A" and "B" was 3.68\% and 6.30\%, respectively. On the other hand, the carbon obtained from orange peels had an efficiency of $5.00 \%$ and $2.88 \%$, respectively. To confirm that the activated carbon from each type of waste has adsorption and absorption capacity, we performed a colorimetric analysis with methyl blue. These analyses showed that the activated carbon from coffee grounds and orange peels have a retention capacity of 91.09 and $95.25 \%$, respectively, while the retention capacity of a commercial activated carbon was $99.23 \%$. In this preliminary study, it is shown that several residues considered "garbage" can be used sustainably.
\end{abstract}

Keywords: absorption, adsorption, activated carbon, orange peels, coffee residues

\section{Introduction}

Over the last few years, the problem of solid waste management in Mexico has increased, not only with accentuations in waste volumes due to population growth, but also due to the transformations that have been registered in the composition of the waste (National Institute of Statistics and Geography [INEGI], 2019). In addition to this problem, Mexico lacks the technology to manage organic and inorganic waste, also, there are no regulations that require industry to use products with recyclable packaging. Additionally, ordinary citizens, have no culture of recycling waste that could have a sustainable use. One of the industries that have has this problem is the coffee industry. The local demand and international coffee production in the period 2007-2016 has increased, due to the fact that the production and consumption of coffee in the world increased an annual average of $3.0 \%$ and $2.5 \%$, respectively (Ministry of Agriculture, Livestock, Rural Development, Fisheries, and Food [SAGARPA] , 2016a). On the other hand, in Mexico, orange production takes place in 24 regions known as Fruit Producing Areas. Region 1 which covers the state of Yucatan and region 3 which covers the state of Campeche, Chiapas, Tabasco, and Quintana Roo; these regions, have been cataloged as strategic regions for orange production according to data from SAGARPA in 2016 , and, as a consequence, it is expected that the global demand will increase in a $13.08 \%$ in 2030 (SAGARPA, 2016b). These data is very favorable for the national market of coffee and oranges; however, there is no management and use of waste from consumption. The use of organic waste is an excellent strategy to transform material that is considered garbage. Some studies, such as the one conducted by Kabenge et al. (2018) show that banana peels can be reused by subjecting them to a high-temperature treatment, obtaining vinegar from this raw material. Other group performed a chemical characterization of the pyrolysis (carbonization) of banana peels Using different treatments with the aim of evaluating the use of waste as biomass, they generate energy from products obtained by combustion, generating a considerable caloric value to generate energy through it (Ribas, Fernandes, Marangoni, Souza \& Sellin, 2013). Even the use of microalgae such as Spirulina $s p$, can produce enough biomass to generate sustainable oil and fuel (Chaiwong, Kiatsiriroat, Vorayos, \& Thararax, 2013).

Furthermore, another way to take advantage of lignocellulosic materials and vegetable waste rich in coal, is to obtain activated carbons from them (Vargas, Giraldo, \& Moreno, 2008). The term activated carbon refers to a 
series of very porous carbon, produced from carbon-rich materials (Luna, González, Gordon \& Martín, 2007). This material has a high absorption capacity, since it has a system of branched hexagonal pores of carbon atoms that lack crystallographic order, which allows substances to be sucked into the interior and retained there (Figueiredo, Pereira, Freitas \& Órfão, 1998; Manals, Vendrell, \& Penedo, 2015). Moreover, activated carbon has the potential as a filter of adherent impurities. This capacity is caused by a not mechanical electrochemical attraction process, thus considered highly efficient in filtering processes (Carriazo, Saavedra, \& Molina, 2010). Activated carbon has variable diameters, with ranges from micropore (less than $0.2 \mathrm{~nm}$ ), mesoporous (between 2 and $50 \mathrm{~nm}$ ), and macropore (greater than $50 \mathrm{~nm}$ ). The different porous characteristics of activated carbon give it the ability to filter bacterial molecules causing odors, flavors, colors, as well as bacteria such as Escherichia coli, all depending on the pore size (Giraldo, L., García, V., \& Moreno, 2008; Lavado, Sun, \& Bendezú, 2010; Romeu, 2012; Zaparolli, 2013). It has also been shown that activated carbon is capable of absorbing and retaining synthetic dyes used in the manufacture of textiles, which are often found in water bodies as a result of their wide industrial use, becoming agents that affect the environment (Giraldo et al. 2008). Additionally, it has also been used to retain metallic ions such as nickel, copper, iron, and cobalt, from in water treatment processes (Manals et al. 2015). In the preparation of activated carbons, the material is calcined or pyrolyzed (carbonization) and then subjected to the activation process. The activation process leads to an increase in the porosity and adsorption capacity of the carbonized material through oxidation of the functional groups of the solid surface (Rojas-Morales, Gutiérrez-González \& Colina-Andrade, 2016). For example, the activated carbon obtained from organic wastes like coconut and pine residues, are among the most commonly used in the food and pharmaceutical industry for many different purposes, such as toothpaste, facial treatment, etc. (Carriazo et al. 2010).

Due to the problems exposed above, the present study focused on implementing a protocol for the waste management of coffee (roasted and ground coffee waste, generally used in coffee machines) and orange peels waste as a source of activated carbon with a low cost, and consequently, reducing the environmental impact generated by their consumption.

\section{Materials and Methods}

\subsection{Obtaining and Preparing the Raw Material}

The residues were obtained from roasted and ground coffee (Coffea arabica) that normally are discarded after preparing coffee to drink. These residues are referred as "coffee grounds". These coffee grounds were dried at room temperature for 48 hours (h). On the other hand, residues of oranges (Citrus sinensis) were collected from local food stores. The peels were separated manually from other organic materials to subsequently be dried inside an oven (VGH model: 33) during $2 \mathrm{~h}$. After this time, the peels were cut in slices of $\leq 0.5 \mathrm{~cm}^{2}$ approximately.

\subsection{Pyrolysis}

Fifty grams (g) of coffee grounds and orange peels, each in independent experiments, were placed in porcelain mortars and subjected to pyrolysis at $500{ }^{\circ} \mathrm{C}$ for $1 \mathrm{~h}$ in a muffle (NOVATECH). For later, the material let cool to room temperature (based on Vargas et al, 2008; Fernandes et al. 2013 modified). This process was repeated in three independent experiments.

\subsection{Chemical Activation}

The carbon previously obtained from the pyrolysis of coffee grounds and orange peels was incubated for $16 \mathrm{~h}$, at room temperature, in a solution of $50 \%$ phosphoric acid $\left(\mathrm{H}_{3} \mathrm{PO}_{4}\right)$ diluted in distilled water. After this time, the material was filtered and submitted the following protocols (Rojas Morales et al. 2016 modified):

Protocol A: The material was washed twice with distilled water and stored until its use.

Protocol B: The material was submitted to a second pyrolysis process at $500{ }^{\circ} \mathrm{C}$ for $1 \mathrm{~h}$, and allowed to cool for 15 to 20 minutes $(\mathrm{min})$ at room temperature. The material obtained was washed, dried, and stored until use (Carrizo et al. 2010 modified).

\subsection{Neutralization of Activated Carbon}

Each sample was resuspended in $50 \mathrm{ml}$ of a solution containing 1.5 molar (M) of $\mathrm{NaOH}$, and incubated in agitation at $120 \mathrm{rpm}$ at room temperature for $2 \mathrm{~h}$. Subsequently, the samples were filtered and incubated for $48 \mathrm{~h}$ in $50 \mathrm{ml}$ of a solution containing $1 \mathrm{M}$ of $\mathrm{NaOH}$ for neutralization. After this time, the activated carbon obtained was placed in porcelain mortars and dried for $1.5 \mathrm{~h}$ at $175^{\circ} \mathrm{C}$. Finally, the activated carbon was weighed and stored until use (modified from Castellar et al. 2017). 


\subsection{Colorimetric Test}

For colorimetric test, a solution containing $0.01 \% \mathrm{v} / \mathrm{v}$ of methylene blue was prepared and used as stock. Likewise, a standard curve was elaborated with the following concentrations of $0.01,0.001,0.0001,0.00001$ and $0.000001 \% \mathrm{v} / \mathrm{v}$. and measure their absorbance (abs) in the spectrophotometer at a wavelength of 664 nanometers (nm) (in three independent experiments). Subsequently, in order to evaluate the absorption and adsorption of the activated carbon obtained from coffee grounds and orange peels, $1 \mathrm{~g}$ of activated carbon from each compound were put on filter paper ( $40 \mathrm{~nm}$ pore) placed in a funnel. Afterwards, $10 \mathrm{ml}$ of the stock solution containing $0.01 \%$ of methylene blue was passed through funnels. The filtered solution was recovered and the absorbance was measure with a spectrophotometer (HACH model: DR3900) at a wavelength of $664 \mathrm{~nm}$. Commercial activated carbon obtained from coconut shells were used as positive control (product name Rapunzel). Analyses were performed in three independent experiments at room temperature (modified from Rojas Morales et al. 2016).

\section{Results}

\subsection{Efficiency in Obtaining Activated Carbons from Coffee Grounds and Orange Peels}

For the production of activated carbon from coffee grounds, $50 \mathrm{~g}$ of dry coffee and orange peels residues were carbonized, chemically activated and neutralized for to submit them to protocols A and B. In the case of coffee residues, the protocol A produced $1.84 \mathrm{~g}$ of activated carbon obtaining an efficiency of $6.30 \%$ considering the $50 \mathrm{~g}$ used as $100 \%$. In the case of protocol "B", the final weight was $3.15 \mathrm{~g}$, with an efficiency of $3.68 \%$. On the other hand, the activated carbon from orange peels, produced $2.50 \mathrm{~g}$ for protocol "A" with an efficiency of $5 \%$, and $1.44 \mathrm{~g}$ with protocol "B" with an efficiency of $2.88 \%$. Figure 1 shows the three different stages in the production of activated carbons.

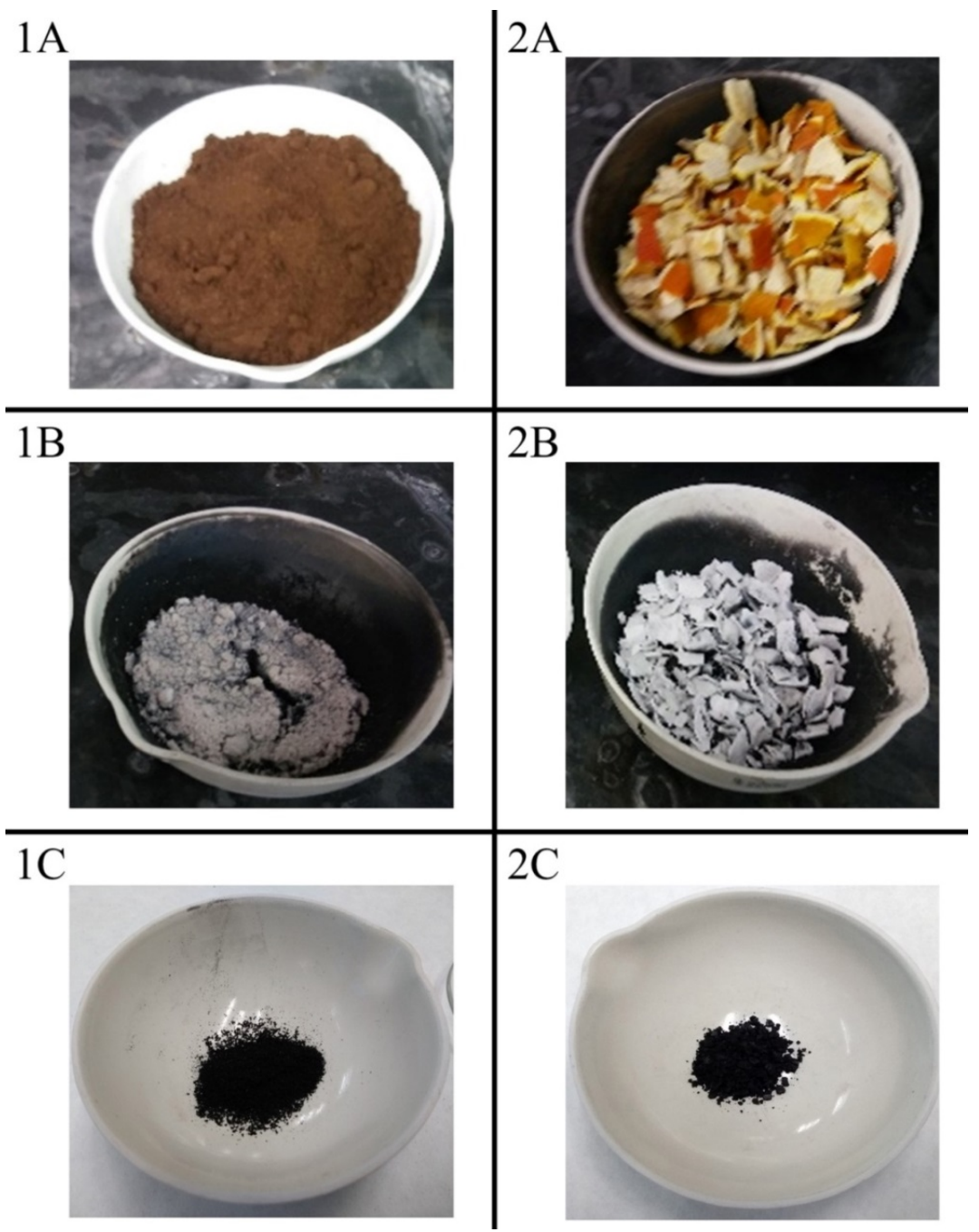

Figure 1. Activated carbon obtained from coffee and orange residues. Column 1: Coffee grounds, Column 2: Orange peels; Line A: Raw material, Line B: Raw material after carbonization, Line C: Final product 


\subsection{Absorption and Adsorption Capacity of the Activated Carbon Obtained from Coffee Grounds and Orange} Peels

The adsorption and absorption capacity of activated carbons from coffee grounds and orange peels were evaluated by colorimetric tests. These tests used the methylene blue as a direct indicator for the standard curve, as mentioned above in the Methods section. The results listed in on Table 1 shows the absorbance obtained in the colorimetric assay, as well as the percentage of methylene blue present in the filtrates obtained from each one of the samples from each protocol.

Table 1. Content of methylene blue in the filtrates

\begin{tabular}{llll}
\hline Sample & Protocol & Absorbance & Concentration (\%) \\
\hline Control (-) & & 1.1714 & 99.99 \\
Control (+) & & 0.018 & 0.76 \\
Coffe & A & 0.0785 & 59.66 \\
Coffe & B & 0.0195 & 8.9 \\
Orange & A & 0.027 & 15.35 \\
Orange & B & 0.0146 & 4.74 \\
\hline
\end{tabular}

We used the results of Table 1, to calculate the percentage of methylene blue retention of the samples (Figure 2). The high retention levels were of $91.09,84.64$ and $95.25 \%$ that, corresponding to CoffeB, OrangeA, and OrangeB, respectively. If compared with $99.23 \%$ of the positive control and $0.001 \%$ of the negative control. We found a good efficiently and efficacy of the activate carbons; in the capacity of containing molecules of color. Furthermore, the statistical analyzing used T-test, did not show statistically significant differences versus the positive control. While, the protocol CoffeA does show significant differences versus the positive control and the CoffeB $(\mathrm{p}<0.001)$ (Table 2). To shows the figure 2, the retention percentage of the samples, the bars represent the means obtained and the standard deviation.

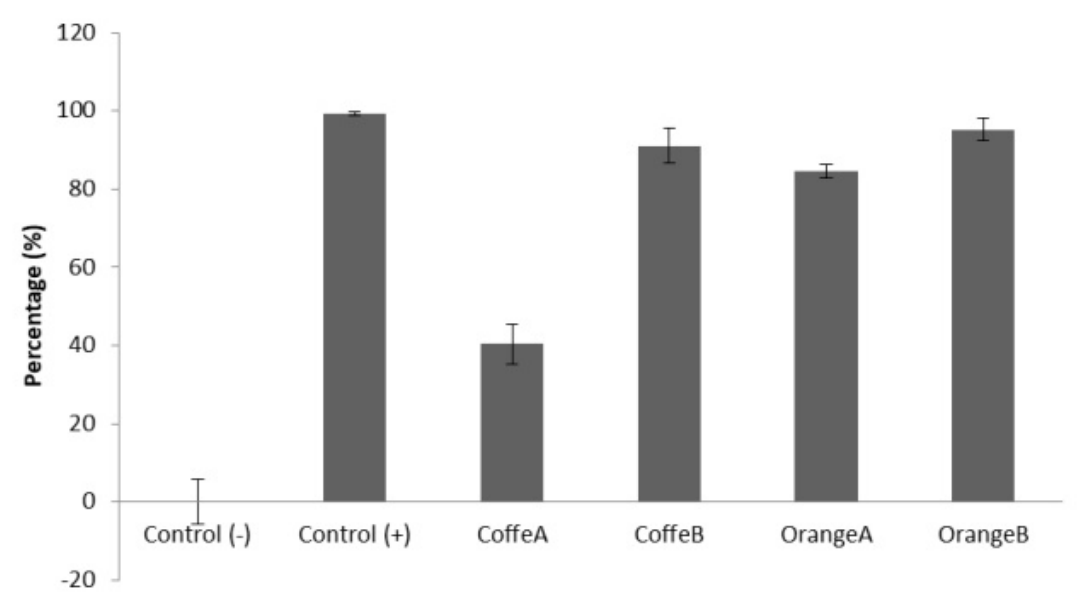

Figure 2. 
Table 2. Paired samples T-Test

\begin{tabular}{|c|c|c|c|c|}
\hline & & $\mathbf{t}$ & df & $\mathbf{p}$ \\
\hline$\overline{\operatorname{Ctrol}(+)}$ & - $\quad$ CoffeA & -19.013 & 3 & $<.001$ \\
\hline Ctrol(+) & - $\quad$ CoffeB & -0.258 & 3 & 0.813 \\
\hline Ctrol(+) & - OrangeA & -1.518 & 3 & 0.226 \\
\hline Ctrol(+) & - $\quad$ OrangeB & 0.563 & 3 & 0.613 \\
\hline CoffeA & - $\quad$ CoffeB & 21.025 & 3 & $<.001$ \\
\hline CoffeA & - OrangeA & 10.141 & 3 & 0.002 \\
\hline CoffeA & - OrangeB & 10.420 & 3 & 0.002 \\
\hline
\end{tabular}

Note. Student's t-test.

\section{Discussion}

The problem of garbage have increased by the excessive increase in population and consumerism, which takes little into account the impact that this produces to the ecosystems; with these two problems Mexico shows deficiency management of organic and inorganic waste that urgently requires and needs solutions. One of the options is to look for strategies that allow reuse and take advantage of waste considered "garbage" and generate from the new products, allowing sustainable use of resources. The present study focuses precisely on looking for alternatives to utilize these organic wastes in Cancun, Quintana Roo, specifically coffee grounds (used coffee) and orange peels, this to reduce the environmental impact already generated by consumption.

The results of the protocol CoffeA shows the best finally yield with $6.30 \%$ versus the protocol CoffeB with $3.68 \%$.Maybe, this result could be little; however, the group by Grisales \& Wilmer (2016), to demonstrate that starting to $12 \mathrm{~kg}$ of pulp of coffee obtained a yield of $6.66 \%$. This yield is similar to get in the protocol CoffeA, though the protocol CoffeB the yield is lower. In other hand, the analysis of the finally yield from orange peels, To indicate for the protocol OrangeA was of $5.00 \%$, while that for the protocol OrangeB was $2.88 \%$.The yields are good, if we consider the process of pyrolysis and chemical were subjected the carbons. Also remember that, to obtain activated carbons from coffee and orange waste, so it does not involve an additional cost and it is a sustainable management of solid waste.

The group by Castellar et al. (2017) publishes that the activated carbon is capable of retaining and absorbing synthetic colorants. The activate carbon used in the manufacture of textiles that "pollute of water". Nevertheless, it is necessary to evaluate the retention capacity of the activated carbon to be, used as a filter for this dye. For this reason, the present study evaluated the capacity of retention methylene blue by the activated carbons generated. The results indicated that the activated carbon CoffeB presents the best capacity of retention with $51.57 \%$ more than CoffeA. While, the positive control presented a $99.23 \%$ of retention, the difference in the capacity of retention between CoffeB and commercial carbon, is of $8.14 \%$.This strongly suggests that the CoffeB has a good potential of retaining particular molecules of color. In addition, the statistical test does not show significant differences between the positive control and CoffeB, unlike CoffeA. This capacity of retention according to data by Castellar et al. (2017) evaluated the commercial DB2 colorant is good, even similar of the commercial carbons. The group also suggests that acidifying slightly; the activated carbon increases the capacity of retention, because the $\mathrm{pH}$ of the dissolution is an important parameter in the process of adsorption, since it can affect the interaction of the superficial functional groups of the adsorbate and the adsorbent. Furthermore, the properties of activated carbon and colors may indicate whether adsorption is favorable in acid or basic solutions.

To analyze the retention capacity of activated carbon from orange peels, the tests showed that the protocol OrangeA and OrangeB have differences of $10.61 \%$. We found that these results are similar at the positive control in the capacity of retention of molecules of color. Also does not detected statistically significant differences. We suggest that both protocols are adequate. Yet, the protocol OrangeA is considered more optimal in terms of production time, because it takes less time to obtain. According to data obtained from (Vargas et al, 2008), they demonstrate that the different forms of chemical and pyrolysis activation as well as the origin of the raw material influence the capacity of the activated carbon to retain and absorb elements and/or particles, due to the size of the pore (micropore, mesopore and macropore) that is generated (Vargas et al, 2008; Carriazo et al, 2010). For this reason, we can say that both protocols CoffeB and OrangeB comply with the objective to remove more than 
$90 \%$ of the methylene blue molecules. Though, we suggest analyze, it is possible to increase their absorption capacity by combining both carbons. We can suppose that the difference in absorption of activated carbons from coffe and orange is due the size pore, however more analysis is required to prove this. We know that complementary analysis such as scanning microscopy, X-ray diffraction, etc. are required to characterize pore texture, surface area, and pore volume. These tests will allow us to confirm our hypotheses regarding their retention capacities by raw material origin.

To generate activated carbon from these wastes "a low cost". To provide a solution and sustainable use of these wastes. This would otherwise end up in the municipal landfill, causing environmental impact problems. According to data from the State Attorney's Office for Environmental Protection and the State Secretariat of Ecology and Environment in 2018, the inter-municipal landfill between Cancun and the municipality in Isla Mujeres are becoming a great environmental danger, due to the lack of space in the sanitary landfill. This is causing an increasingly overpopulated, polluted and chaotic situation. Producing extreme biotic fragility and intensive demography, causing inevitable and vertiginous destruction. In this study we propose an alternative use and management of these wastes, we know that it is a serious problem and that it is just an approach to solve the problem; however, we consider it is a beginning to address this problem that not only it includes the state of Quintana Roo, but all of Mexico.

\section{Conclusion}

It was possible to standardize the obtaining of activated carbon from two important residues in our locality (orange peels and coffee grounds), allowing sustainable use at a low cost. In this study; protocol B, was the best result, exceeding $90 \%$ particle retention, regardless of the raw material. The best activated carbon was OrangeB, which shows $95.25 \%$ methylene blue retention. However, the activated carbon obtained of protocol B coffee grounds is the that presents the smallest statistical difference versus the positive control. Besides, the correct standardization of the production processes was achieved at a very low cost.

\section{Acknowledgements}

Thanks are due to Dr. Iris Aurora Nava Jiménez and Engineer Tania H. Luz Montoya for their support and resources provided in the Biotechnology laboratory. Thanks are also due to the Universidad Politécnica de Quintana Roo, in particular to the Biotechnology Engineering Education Program. Finally, we would like to thank Engineer José Israel Jiménez Petul for his collaboration on carrying out experiments.

\section{References}

Carriazo, J. G., Saavedra, M. J., \& Molina, M. F. (2010). Propiedades adsortivas de un carbón activado y determinación de la ecuación de Langmuir empleando materiales de bajo costo. Educación Química, 21(3), 224-229.

Castellar, G. C., Viloria, C. A., Morrison, B. C., Angulo, M. R., \& Zambrano, A. A. (2017). Evaluación de un carbón activado comercial en la remoción del colorante DB2. Revista colombiana Ciencia Animal, 9(2), 164-170. https://doi.org/10.24188/recia.v9.n2.2017.512

Chaiwong, K., Kiatsiriroat, T., Vorayos, N., \& Thararax, C. (2013). Study of bio-oil and bio-char production from algae by slow pyrolysis. Biomass and Bioenergy, 600-606. https://doi:101016/jbiombioe201305035

Fernandes, E. R. K., Marangoni, C., Souza, O., \& Sellin, N. (2013). Thermochemical characterization of banana leaves as a potential energy source. Energy Conversion and Management, 75, 603-608. https://doi.org/10.1016/j.enconman.2013.08.008

Figueiredo, J., Pereira, M. F., Freitas, M. M., \& Órfão, J. J. (1998). Modification of the surface chemistry of activated carbons. Carbon, 37, 1379-1389.

Giraldo, L., García, V., \& Moreno, J. C. (2008). Caracterización superficial en fase gas y líquida de carbones activados. Revista de Ingeniería, (27), 7-16.

Grisales-Motato, A. L., \& Wilmer-Rojas, A. (2016). Obtención de carbón activado a partir de activación química de pulpa de café y su aplicación en la remoción de colorantes en aguas residuales industriales, (Engineer's thesis Universidad Tecnológica de Pereira, Pereira).

Kabenge, I., Omulo, G., Banadda, N., Seay, J., Zziwa, A., \& Kiggundu, N. (2018). Characterization of Banana Peels Wastes as Potential Slow Pyrolysis Feedstock. Journal of Sustainable Development, 11(2). https://doi.org/10.5539/jsd.v11n2p14

Lavado, M. C., Sun, K. M., \& Bendezú, S. (2010). Adsorción de plomo de efluentes industriales usando 
carbones activados con $\mathrm{H}_{3} \mathrm{PO}_{4}$. Revista Sociedad Química Perú, 76(2).

Luna, D., González, A., Gordon, M., \& Martín, N. (2007). Obtención de carbón activado a partir de la cascara de coco. Rev. Colombia de química, 64, 39-48.

Manals, C. E., Vendrell, C. F., \& Penedo, M. M. (2015). Aplicación de carbón activado de cascarón de coco en adsorción de especies metálicas contenidas en el licor de desecho (WL) de la lixiviación ácida de mineral laterítico. Tecnología química, 36(1), 93-103.

National Institute of Statistics and Geography. (2019). Residues Solidus, Mexico. Retrieved from https://www.inegi.org.mx/temas/residuos/

Ribas, E., Fernandes, K., Marangoni, C., Souza, O., \& Sellin, N. (2013). Thermochemical characterization of banana leaves as a potential energy source. Energy Conversion and Management, 75, 603-608. https://dx.doi.org/10.1016/j.enconman.2013.08.008

Rojas-Morales, J. L. , Gutiérrez-González, E. C., \& Colina-Andrade, G. J. (2016). Obtención y caracterización de carbón activado obtenido de lodos de plantas de tratamiento de agua residual de una industria avícola. Ingeniería Investigación y Tecnología, XVII(04), 453-462. https://doi:10.1016/j.riit.2016.11.005

Romeu, A. B. (2012). Caracterización de cepas de Escherichia Coli de importancia clínica humana aisladas de ecosistemas dulceacuícolas de la habana (doctoral's thesis Universidad de la Habana. Habana). Retrieved from http://tesis.sld.cu/

Secretary of Agriculture and Rural Development. (2016a). Planeación agrícola Nacional 2017- 2030 Café Mexicano. México. Retrieved from https://www.gob.mx/cms/uploads/attachment/file/256426/B_sico-Caf_.pdf

Secretary of Agriculture and Rural Development. (2016b). Planeación agrícola Nacional 2016- 2030 Cítricos Limón, Naranja y Toronja Mexicanos. México. Retrieved from https://www.gob.mx/cms/uploads/attachment/file/257073/Potencial-C_tricos-parte_uno.pdf

Vargas, J. E., Giraldo, L., \& Moreno, J. C. (2008). Obtención y caracterización de carbones activados a partir de semillas de Mucuna sp. Revista Colombiana de Química, 37(1), 67-77.

Zaparolli, Z. J. (2013). Determinación de la dosificación óptima de carbón activado y tierra diatomacea, para la remoción de color de licores de azúcar derretida en la fabricación de azúcar refino (Engineer's thesis Universidad de San Carlos de Guatemala. Guatemala). Retrieved from http://biblioteca.usac.edu.gt/tesis/08/08_1286_Q.pdf

\section{Copyrights}

Copyright for this article is retained by the author(s), with first publication rights granted to the journal.

This is an open-access article distributed under the terms and conditions of the Creative Commons Attribution license (http://creativecommons.org/licenses/by/4.0/). 